\title{
A Personal Perspective on the Fight Against HIV/ AIDS in China
}

\section{Meng Lin}

\section{Q OpenEdition}

1 Journals

\section{Electronic version}

URL: http://journals.openedition.org/chinaperspectives/4765

DOI: $10.4000 /$ chinaperspectives. 4765

ISSN: 1996-4617

\section{Publisher}

Centre d'étude français sur la Chine contemporaine

\section{Printed version}

Date of publication: 1 April 2009

Number of pages: 4-6

ISSN: 2070-3449

\section{Electronic reference}

Meng Lin, «A Personal Perspective on the Fight Against HIV/AIDS in China », China Perspectives [Online], 2009/1 | 2009, Online since 01 April 2011, connection on 28 October 2019. URL : http:// journals.openedition.org/chinaperspectives/4765; DOI : 10.4000/chinaperspectives.4765 
C

A Personal Perspective on

\title{
the Fight Against HIV/AIDS
}

\section{in China}

\author{
MENG LIN
}

In this testimony, Meng Lin, a person living with HIV/AIDS (PLWHA) in China and at the same time an activist engaged in the fight against the epidemic, shares his insight into the current situation from both a personal and professional perspective. In the latter case, he speaks in his capacity as founder of Ark of Love, an association that aims to inform and help PLWHA to organise themselves and set up their own structures for mutual aid and defence of their rights.

\section{My personal experience}

$0^{2}$ ince I was diagnosed positive in 1996, I have witnessed at first hand the arrival of the epidemic in China, the development of the government response to it, and the emergence of the non-governmental sector. Following my diagnosis, I was sent to the You'an hospital in Beijing. At that time, there was no treatment available in China for people living with HIV/AIDS, and everyone in the hospital, medical staff and patients alike, was both ignorant about the disease and terrified of it. Faced with widespread discrimination and the huge stigma attached to being HIV-positive, I lost all hope. But Dr. Xu Lianzhi of the hospital's Department of Infectious Diseases gradually helped me to regain my strength and my faith in life. In spite of the hostile social environment of the time and the non-availability of treatment, she never ceased to encourage me.

I shall always be grateful to this doctor, whom I now look on as my mother, for the fact that in the years that followed I was able to pick myself up and have never stopped fighting both the disease and the injustices against myself and my fellow-sufferers. My commitment to the fight against HIV/AIDS has grown alongside my wish to help the community of victims of this epidemic. Now, more than ever, they need to unite, in order to take part in the battle against discrimination and the struggle for access to treatment. It is in fact their participation that gives meaning to this process and will ensure its outcome. I set up Ark of Love in 2004 with the aim of encouraging such participation. We use a wide variety of means to get across both the knowledge and the capacity necessary for the meaningful engagement of PLWHA in China. At the beginning, it was simply a question of having an Internet discussion forum and organising regular activities. Since then, we have started working in Beijing's You'an hospital itself, and we now receive support from several different foundations. As examples of the many initiatives and activities of Ark of Love today, we can flag the publication of Women de shengyin (Our voice), a free magazine that gives a voice to PLWHA, and the recent opening of the first on-line chatroom devoted to issues connected with AIDS and set up, with PLWHA in mind, to compensate for the over-supply of such Internet sites that did not allow adequate access.

Using examples both from my own experience and from the collaborative work carried out in Ark of Love, I will first of all give an overview of the present situation and the main difficulties encountered by PLWHA in China, and will then go on to describe in more detail the principles of GIPA (Greater Involvement of People living with HIV/AIDS). I will discuss these people and their communities, as well as their respective needs in the Chinese context.

\section{Main difficulties and the present situation of PLWHA in China}

An estimated 700,000 people are living with HIV in China today. That large number does not include family members and others close to PLWHA, who on a daily basis have to 
cope with difficulties of such a practical and existential nature that AIDS cannot be seen simply as a public health issue; it has to be viewed as a social problem that affects the whole of society. In spite of recent changes to public health policy that have tried to tackle this situation, the treatment and living conditions of the great majority of AIDS sufferers remain very problematic, and the implementation of government policies at the grassroots is nowhere near complete.

\section{Access to treatment and care}

The main problem is access to treatment: in this regard, conditions in China are still far from the norms recommended by the World Health Organisation (WHO). Although in theory second-line treatment is now available thanks to the government's "Four frees and one care" policy announced prior to the Olympics, its availability in practice remains very limited. Moreover, certain costs, such as those associated with the treatment of opportunistic diseases, must be borne by the patient, and most patients have no means of paying them. In addition, even though the legal framework has recently been improved, many hospitals still refuse to provide even the most basic care for PLWHA. This is especially obvious in the case of surgical operations: very few hospitals agree to help PLWHA who require this type of care. Sadly, experience has recently shown us once again that even in a hospital well-known in Beijing for the advances it has made in the treatment and acceptance of PLWHA, the "squandering" of such care on this type of patient is not accepted throughout the system.

\section{Problems relating to social inclusion and discrimination}

There are also very real difficulties with regard to access to work, which by guaranteeing PLWHA social inclusion and economic independence is just as necessary as access to treatment. When they reveal their condition, or when it is made known through a breach of medical confidentiality, PLWHA are all too often dismissed from their jobs for no good reason. Discrimination is also, sadly, found among family members, who because they object to the life-styles associated with the condition and are afraid of contamination, reject their closest relatives and deprive them of even basic social and psychological support. This is why PLWHA rarely choose to disclose their condition.

As a result, either because they are afraid of what such a revelation might bring, or because the fact that they are
HIV-positive has already been revealed, the majority of PLWHA prefer to conceal their condition and are thus forced into solitude and isolation. In the face of the extreme social pressures to which they are subjected, some of them react in a manner that is also extreme - they give up the will to live, and let themselves be carried off by the virus. It is therefore not surprising that some of us take our own lives so as to pre-empt the disease. Many others start living an "underground" life, the illegal aspects of which makes them even more vulnerable to dangers of all kinds. In addition, such marginalisation places the whole of society in danger, because it privileges types of infection that are even harder to combat.

In connection with the question of discrimination, I am keen to raise a point here that is all too often overlooked. It is true that discrimination against PLWHA was initially due to misinformation in the media and the ignorance of the general population about an illness that has terrifying consequences and origins. However, it is also partly due to the behaviour of PLWHA themselves, because most of them either refuse to admit that they are HIV-positive, or feel compelled not to do so. In their desire to be part of society, they conceal their true identity and all aspects of their life that might not be understood or might be rejected by so-called "normal" people. This is what I call "self-discrimination." It entails psychological consequences that only serve to worsen the already fragile condition of their lives: loss of self-confidence, fear of the Other, the sense that they are to blame, and so on. But it is also certain that if all PLWHA accept such social discrimination by internalising it in this way, the stigma will continue to tarnish the image of PLWHA for ever, and none of them will be able to see that there can be a tomorrow, that they are allowed to have hope, and that they are not destined to permanent solitude. Who is going to respect us, who will help us, if we don't do it ourselves?

\section{Involvement of PLWHA in community organisations}

\section{GIPA and civil society in China}

The awareness of the role that PLWHA have to play in the fight against AIDS is a consequence of a principle promoted internationally by UNAIDS (the Joint United Nations Programme on HIV/AIDS) using the acronym GIPA (Greater Involvement of People living with HIV/AIDS). This principle was officially formulated at the AIDS summit 
in Paris in 1994, in a convention signed by 42 nations, including China. In June 2001, the Chinese government solemnly expressed its commitment to it by signing the "Declaration of Commitment on HIV/AIDS" under the aegis of UNAIDS. The text of the document formally recognises the importance and necessity of the contributions made by PLWHA, by young people, and by civil society to all aspects of the response to AIDS. It is now no longer possible to ignore the official recognition given to these principles, or the commitment made by the Chinese authorities to the international community.

As far as civil society is concerned, I am very conscious of the particular nature of the Chinese context. Nevertheless, this particularity is not, in principle, opposed to the fruitful participation of non-governmental organisations, whatever they may be. Indeed, the aim of these NGOs is not to oppose the government but to use local knowledge to help to overcome any deficiencies that may appear in the policies the government introduces. Thus, in March 2006, the State Council of the PRC gave clear recognition to the principle of the participation of society as a whole in the fight against the epidemic in the "Regulations on AIDS prevention and control." Madame Wu Yi, then a vice-premier of the State Council, declared that "the fight against AIDS must be carried out alongside NGOs." However, it is still very difficult for local community organisations to exist legally, and this means their activities are somewhat precarious and they have no guarantees as to the longevity of any initiatives they may take.

Behind this commitment on the part of the authorities and the support advertised by those in positions of responsibility, there are actually still many obstacles that hinder the attempts of PLWHA at the local level to apply the principles of GIPA and those inherent in the concept of civil society. Generally speaking, the lack of a favourable environment does not encourage effective outcomes for such attempts. There is a clear need for greater tolerance, respect, and understanding for PLWHA, and fairer access to better quality treatment, as well as for stronger support for their efforts to play a role, and media coverage that is more appropriate to these efforts. In addition, it would also seem necessary to put forward the ideas of civic responsibility, resistance to injustice, and positive participation in social development. It is, in fact, in precisely this dynamic that PLWHA must use their ingenuity and must put forward and scale up their needs and personal interpretations of the situation, so that they too can have a hand in the emergence of community mutual aid associations.

\section{What kind of behaviour is possible under these conditions?}

In mainland China, history has certainly seen to it that such concepts, coming as they do from abroad, cannot automatically take root in the local context. Democracy, for example, is an important issue in civil society, in China as elsewhere, and insofar as PLWHA are implicated in the fight against AIDS in China, such a word is not devoid of meaning for me, either. But given the particular context of our country, and the fact that the emergence of community associations is such a recent phenomenon, I do feel it is absolutely essential not to treat the concept too glibly. It can only be applied in China if it is adapted to the local context, or even reinvented by those concerned. It goes without saying that this is a process that can only be completed over the long term, because haste could lead to an abuse of democracy that would serve only the interests of a restricted group of actors. Accordingly, and because these responsibilities were weighing so heavily on me, I decided in July 2008 to step down from the post of representative of Chinese PLWHA at the Global Fund to Fight Against HIV/AIDS, Tuberculosis and Malaria, a post to which I was elected as democratically as possible in April 2007. My resignation by no means signals that I am giving up my efforts to fight against the discrimination and stigma associated with the AIDS epidemic in China. The task of building a solid and well-informed community of PLWHA remains a priority of Ark of Love, and we will continue to lead this battle unremittingly. The line we choose to take involves bringing the perspective of PLWHA to the government, not with the aim of opposing or criticising what the authorities are doing, but in order to have it carried through successfully, while at the same time demanding more justice and more balance. This is the way in which we hope to contribute to the harmonious development of Chinese society.

Our work has been recognised elsewhere recently by an award from UNAIDS in China for "an outstanding contribution in the field of AIDS" and by the Barry and Martin's Trust prize. Such recognition gives us even greater confidence in the future, and we shall never abandon our struggle to create an environment favourable to PLWHA in China.

\section{- Translated by Caroline Masson}

\section{Glossary}

aizhi fangzhou ganranzhe xinxi zhichi zuzhi 愛之方舟感染者信息支 持組織 women de shengyin 我們的聲音 guanyu aizibing de chengnuo xuanyan 關於艾滋病的承諾宣言 aizibing fangzhi tiaoli 艾滋病 防治條例 